\title{
BERBAGAI UPAYA PENCEGAHAN COVID-19
}

\author{
Yuggo Afrianto', Novita Br Ginting ${ }^{2 *}$, Indriyawati ${ }^{3}$, Kalih Puspita Dewi ${ }^{4}$, Muhamad Rizky \\ Fahrezi $^{5}$
}

\author{
1,2,3,4,5Teknik Informatika, Fakultas Teknik dan Sains, Universitas Ibn Khaldun Bogor \\ Email:novitawahab@uika-bogor.ac.id;yuggo@uika-bogor.ac.id
}

Masuk: 05-07-2021, revisi: 19-09-2021, diterima untuk diterbitkan: 06-10-2021

\begin{abstract}
ABSTRAK
Covid-19 merupakan virus jenis baru yang ditemukan di Wuhan, Hubei, China pada tahun 2019, virus ini diberi nama corona virus disease-2019 yang disingkat menjadi Covid-19, WHO (World Health Organization) menyatakan virus ini sebagai suatu pandemi pada 11 Maret 2020. Berbagai pihak berupaya dalam pencegahan dan penanggulangan Covid-19. Namun banyaknya referensi yang ditawarkan dan ketidak selarasan suatu kebijakkan dalam suatu studi, membuat permasalahan kembali di mana masyarakat bingung untuk mengerti upaya apa saja yang baik atau direkomendasikan dengan kebenaran yang dapat dipercaya. Untuk menangani masalah tersebut maka dalam penelitian ini menggunakan Systematic Literature Reviews untuk mencari upaya yang paling banyak direkomendasikan dengan sumber studi yang terpercaya, yaitu jurnal Scopus dan Google Scholar. Hasil penelitian ini memberikan rekomendasi kepada masyarakat tentang apa saja upaya pencegahan Covid-19, untuk mengurangi penyebaran Covid-19 khususnya di Indonesia. 125 jurnal yang relevan berhasil direview, menghasilkan 37 Upaya pencegahan Covid-19. Berdasarkan metode pemeringkatan mendapatkan 10 upaya yang banyak direkomendasi dalam jurnal, yaitu: Social distancing, Karantina/lockdown/PSBB (Pembatasan Sosial Berskala Besar), WFH (Work From Home), Mencuci tangan, Isolasi diri, Memakai masker, Memakai handsanitizer, Menyemprotkan disenfektan, Menjaga imun, dan Tidak menyentuh wajah. Hal menarik yang didapatkan juga dalam penelitian ternyata terdapat upaya yang tidak hanya dibangun berdasarkan ilmu medis, namun juga dikaitkan dengan kepercayaan seperti, Pemasangan Sawen dan Upacara Keagamaan.
\end{abstract}

Kata Kunci: Covid-19; SLR; Upaya Pencegahan Covid-19

\begin{abstract}
Covid-19 is a new type of virus that was discovered in Wuhan, Hubei, China, in 2019. The new kind of virus was given the name coronavirus disease-2019, shortened to Covid-19. WHO declared this virus a pandemic on March 11, 2020. Various parties tried to in the prevention and control of COVID-19. However, the number of references offered and the variance of a policy in a study create problems again. People are confused to understand what efforts are suitable or recommended with trustworthy truths. Hence, this study uses Systematic Literature Reviews to find the most recommended efforts with reliable study sources, namely the Scopus journal and Google Scholar. The results of this study provide recommendations to the public about the efforts to prevent Covid19, to reduce the spread of Covid-19, especially in Indonesia. 125 relevant journals were successfully reviewed, resulting in 37 Covid-19 prevention efforts. Based on the ranking method, 10 efforts are widely recommended in journals, namely: Social distancing, Quarantine/lockdown/LSSR (Large-scale social restrictions), WFH (Work From Home), Washing hands, Self-isolation, Wearing masks, Using handsanitizer, Spraying disinfectants, Maintaining immunity, and Not touch the face. The exciting thing that was also found in the research was that there were efforts that were not only built based on medical science but were also associated with beliefs such as Sawen Installation and Religious Ceremonies.
\end{abstract}

Keywords: Covid-19; SLR; prevention of Covid-19. 


\section{PENDAHULUAN}

Pada tanggal 31 Desember 2019, WHO (World Health Organization) China Country Office melaporkan adanya kasus kluster pneumonia dengan etiologi (penyebab) yang tidak jelas di Kota Wuhan, Provinsi Hubei, China (Moudy \& Syakurah, 2020). Kasus ini terus berkembang sampai pada tanggal 7 januari 2020, dan akhirnya diketahui etiologi dari penyakit ini adalah suatu jenis virus baru yaitu Coronavirus. Corona virus atau Covid-19 merupakan virus jenis baru yang belum pernah diindentifikasi pada manusia (Kementerian Kesehatan RI, 2020).

Munculnya Covid-19 berdampak kerugian yang besar disetiap negara, termasuk Indonesia. Virus ini tergolong baru sehingga banyak masyarakat tidak mengerti cara pencegahan yang baik dan benar (Telaumbanua, 2020). Seiring menyebar nya Covid-19 ke berbagai negara, maka muncul kebijakan dalam upaya pencegahan Covid-19. Indonesia membuat kebijakan diantaranya seperti, dilakukan lockdown ataupun PSBB (Pembatasan Sosial Berskala Besar) (Thorik, 2020), dan juga pencegahan seperti memakai masker, social distancing dan lainnya (Refialdinata, 2020).

Covid-19 bisa menular dari satu manusia ke manusia lainnya, melalui percikan batuk/bersin (droplet). Kita dapat terinfeksi karena menyentuh permukaan yang telah terkontaminasi Covid19, lalu menyentuh sekitar wajah (mata, hidung dan mulut) (Hastuti et al., 2021). Berdasarkan jumlah kasus Covid-19 yang terus meningkat di semua negara. Upaya pencegahan penyebaran Covid-19 harus dilakukan untuk mengurangi kasus positif yang ada di Indonesia maupun Negara lain, banyaknya informasi yang tersebar luas terkait dengan upaya pencegahan Covid-19 ini, membuat masyarakat bingung untuk menentukan upaya apa yang tepat dalam pencegahan penyebaran Covid-19.

Faktor lainnya adalah ketidakselarasan kebijakan pemerintah, seperti penerapan kebijakan PSBB untuk membatasi pergerakan orang dan barang. Namun, pelaksanaan PSBB ini diwarnai dengan ketidakselarasan kebijakan akibat perbedaan kepentingan antara Pemerintah Pusat dan Pemerintah Daerah. Skenario kebijakan PSBB yang bertumpu di daerah membuat PEMDA (Pemerintah Daerah) berjalan dengan iramanya masing-masing. Sementara itu, di wilayah Jabodetabek, efektivitas pelaksanaan PSBB dihadapkan pada tidak selaras nya kebijakan PEMDA dengan kebijakan beberapa kementerian (Kurniawan, 2020). Situasi-situasi tersebut pada akhirnya membuat pemahaman masyarakat mengenai risiko dan penanganan pandemi COVID-19 tidak utuh sehingga menimbulkan kebingungan di masyarakat.

Dari permasalahan di atas maka pada penelitian ini mencari tentang apa saja upaya pencegahan Covid-19, selain itu penelitian ini memberikan kontribusi pengetahuan informasi apa saja yang tepat dan paling banyak direkomendasikan dalam melakukan pencegahan Covid-19. Penelitian ini menggunakan metode SLR (Systematic Literature Review) dengan fokus menjawab research question yaitu Upaya apa saja yang banyak direkomendasikan dalam pencegahan Covid-19?

Pemakaian metode SLR dapat dilakukan dengan cara mereview dan mengidentifikasi jurnal secara sistematis yang setiap prosesnya mengikuti langkah-langkah atau protokol yang telah ditetapkan (Afrianto et al., 2020).

\section{METODE PENELITIAN}

Penelitian ini menggunakan pedoman tahapan pelaporan PRISMA. Berdasarkan pedoman tersebut terdapat beberapa tahap dalam penelitian, yaitu: 1. Mendefinisikan kriteria kelayakan; 2. Mendefinisikan sumber informasi; 3. Pemilihan studi; 4. Proses pengumpulan data; 5. Pemilihan item data. Tahapan penelitian ditunjukkan pada Gambar 1. 


\section{Definisi :}

- Mendefinisikan kriteria kel ayakan

- Mendefinisikan sumber informasi

Pelaksanaan :

- Pemilihan Studi

- Proses Pengumpulan data

- Pemilihan item data

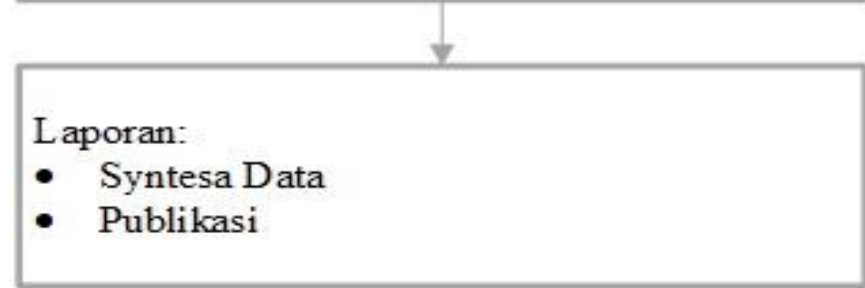

Gambar 1. Diagram Tahapan Penelitian

\section{Definisi}

Definisi merupakan tahap analisa terhadap kriteria kelayakan dan sumber informasi yang akan digunakan dalam penelitian literatur ini. Terdapat beberapa point pekerjaan dalam tahap ini, yaitu:

a. Kriteria kelayakan digunakan untuk mendefinisikan kriteria inklusi (memenuhi kriteria kajian) dan eksklusi (tidak memenuhi kriteria kajian) dalam pencarian literatur. Indikator kriteria inklusi dan eksklusi yang ditetapkan sebagai berikut:

Kriteria Inklusi:

- Sumber informasi merupakan Jurnal.

- Jurnal berjudul tentang Covid-19.

- Publikasi merupakan yang terbaru dengan range tahun 2019-2021 dan terlengkap yang akan dipilih jika ada kesamaan judul atau duplikasi.

Kriteria Eksklusi:

- Publikasi yang tidak melampirkan file pdf.

- Publikasi tidak dalam bahasa indonesia dan bahasa inggris.

b. Sumber Informasi

Penelitian ini menggunakan pencarian sumber database online dengan repositori akademis yang besar, yaitu Google Scholar dan Scopus. Informasi yang tidak dapat diakses akan dihapus dalam sumber informasi penelitian.

\section{Pelaksanaan}

Tahap pelaksanaan merupakan proses pemilihan studi, pengumpulan data, dan proses pemilihan item data.

a. Pemilihan Studi

Pemilihan Studi dalam penelitian ini ditetapkan pada pertanyaan kriteria QA (Quality Assesment) sebagai berikut:

- Apakah paper jurnal membahas mengenai Covid-19?

- Apakah paper jurnal menuliskan metode pengumpulan upaya pencegahan Covid-19? 
$Q A$ digunakan untuk memilih jurnal yang akan digunakan untuk tahap sintesa data, proses dilakukan secara kolaboratif oleh tim peneneliti dengan cara membaca isi dari setiap jurnal yang telah didapat. Jurnal yang tidak memenuhi kriteria $Q A$, maka dibahas oleh tim peneliti hingga mendapatkan kesepakatan apakah layak untuk tahap sintesa data atau dikeluarkan untuk proses selanjutnya.

\section{b. Proses Pengumpulan Data}

Pengumpulan data adalah tahap mengumpulkan sumber informasi untuk bahan penelitian. Data yang dikumpulkan berupa jurnal yang berasal dari Google Scholar dan Scopus. Pengumpulan data dalam penelitian diperoleh melalui beberapa tahap, meliputi:

- Observasi (Pengamatan) merupakan tahap pengumpulan data melalui pengamatan langsung ke sumber infomasi, yaitu: Google Scholar dan Scopus menggunakan software Publish or Perish.

- Dokumentasi merupakan data yang telah dikumpulkan dikelola ke dalam perangkat Mendeley dan Office excell.

Langkah-langkah pengumpulan data mulai dari observasi hingga dokumentasi yang didapat melalui Google Scholar dan Scopus sebagai berikut:

- Membuka software Publish or Perish.

- Memilih pencarian melalui database Google Scholar dan Scopus. Seperti ditunjukkan pada Gambar 2.

\begin{tabular}{|c|c|c|c|c|}
\hline \multirow[t]{6}{*}{ No search selected } & \multicolumn{4}{|c|}{ About the available data sources } \\
\hline & \multicolumn{4}{|c|}{ Select an existing search to inspect or modify it, or click one of these buttons to create a new search. } \\
\hline & Crossref* & $\$$ Microsoft Academic* & & Import External Data... \\
\hline & G Google Scholar * & SC Scopus ${ }^{* 8}$ & & About importing external data \\
\hline & G Google Scholar Profile* & 1) Web of Science ${ }^{* * *}$ & & Free data source \\
\hline & 18 Publed* & & & External subscription required \\
\hline
\end{tabular}

Gambar 2. Pencarian Jurnal Dengan Publish Or Perish

- Google Schoolar dipilih untuk mendapatkan sumber informasi yang berasal dari jurnal publikasi Indonesia. Pada atribut pencarian, memilih tahun 2019 - 2021 untuk menentukan range tahun publikasi, publication name "Jurnal", dengan keywords "(covid 19 OR covid-19 OR covid19) AND upaya pencegahan”. Seperti ditunjukkan pada Gambar 3.

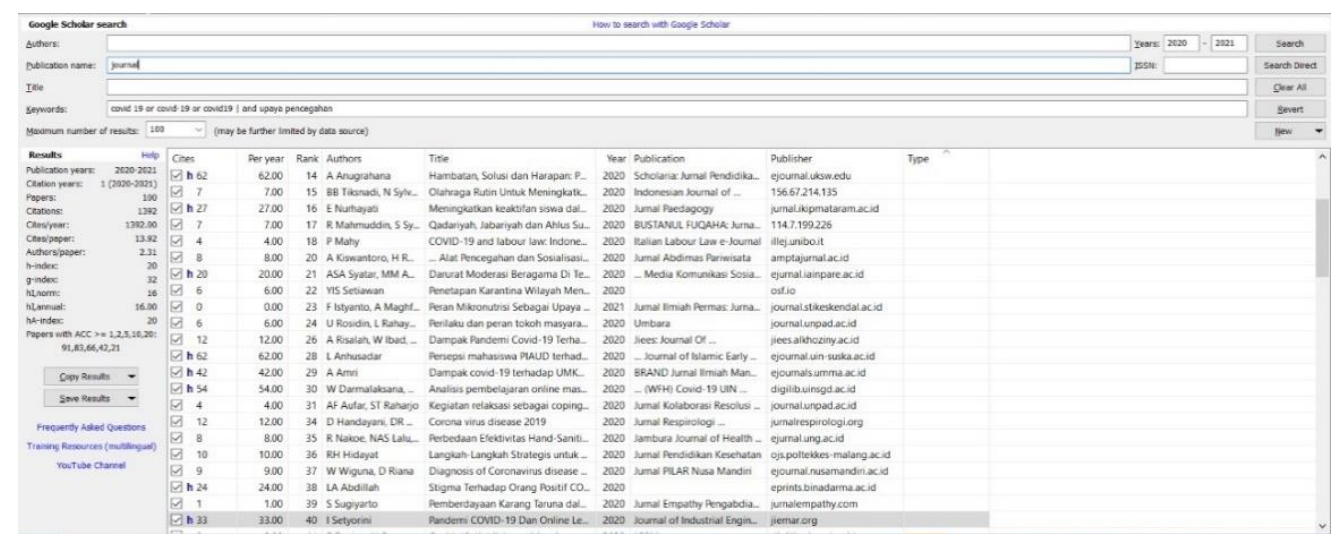

Gambar 3. Hasil Pencarian Keyword pada Google Scholar 
- Scopus dipilih untuk mendapatkan sumber informasi yang berasal dari jurnal publikasi Internasional. Pada atribut pencarian, memilih tahun 2019 - 2021 untuk menentukan range tahun publikasi, publication name "Journal", keywords "(covid 19 OR covid-19 OR covid19) AND prevention efforts". Seperti ditunjukkan pada Gambar 4.

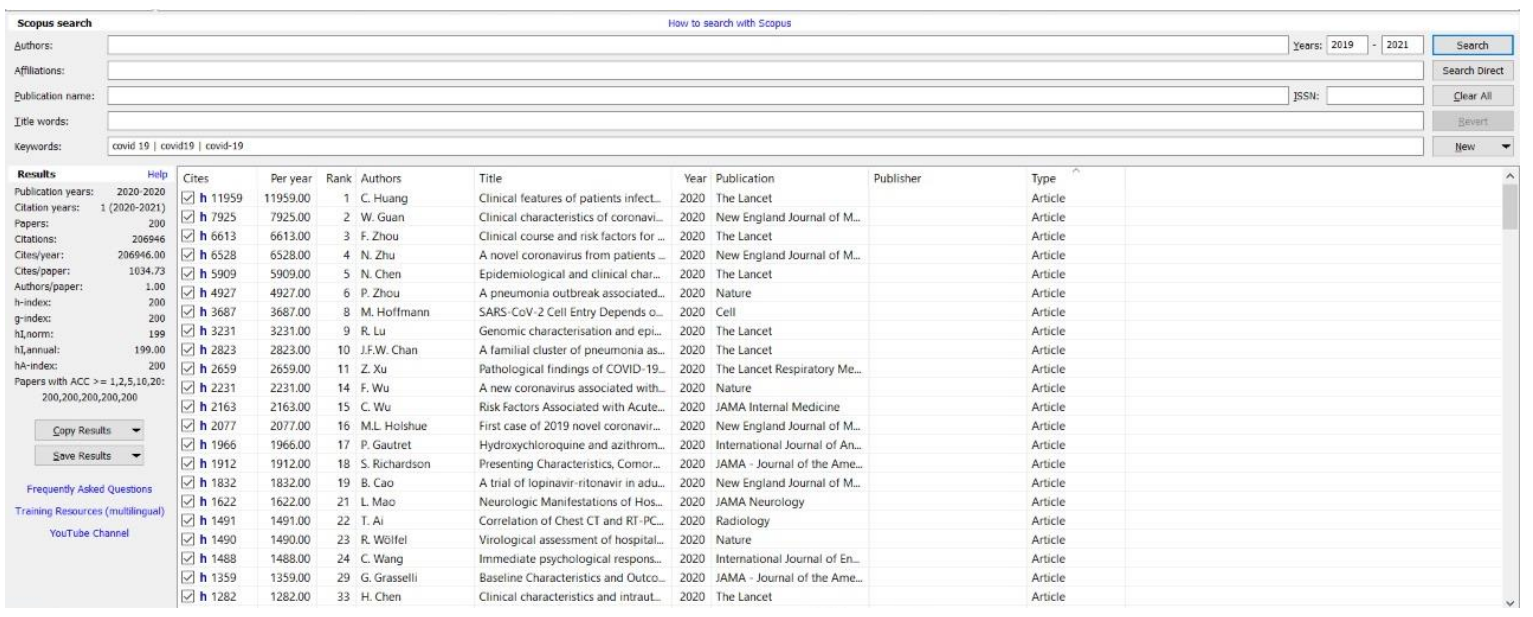

Gambar 4. Hasil Pencarian Keyword pada Scopus

- Hasil pencarian mendapatkan tampilan judul, tahun publikasi, dan nama penulis. Hasil yang ditampilkan oleh pencarian Google Scholar ini sebanyak 100 artikel dan hasil yang ditampilkan oleh pencarian Scopus ini sebanyak 100 artikel.

c. Pemilihan Item Data

Pemilihan item data menggunakan diagram alir Prisma dapat dijelaskan berdasarkan hasil pencarian, seperti ditunjukkan pada Gambar 5.

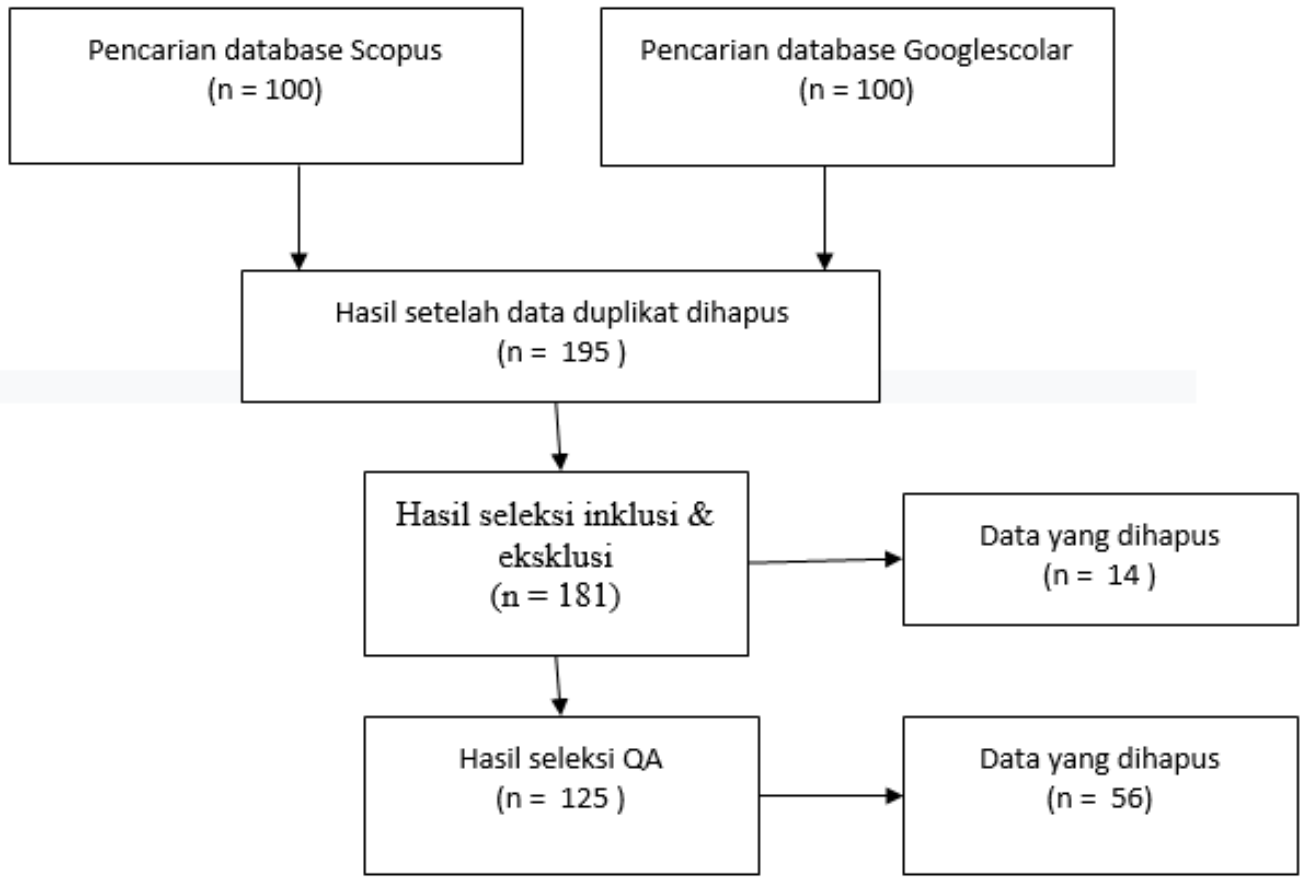

Gambar 5. Alur Pencarian Diagram Prisma 
Mengacu kepada diagram Prisma hasil tahap seleksi kriteria inklusi dan eksklusi didapatkan hasil pada Tabel 1.

Tabel 1. Tabel Seleksi Kriteria Inklusi dan Eksklus

\begin{tabular}{lc}
\hline & Jumlah \\
\hline \multicolumn{1}{c}{ Kotal Jurnal Hasil Pencarian Sumber Informasi Google Scholar dan Scopus } & 200 \\
\hline \multicolumn{2}{c}{ Kotal jurnal terbit pada range tahun 2019-2021 } \\
\hline Total jurnal lengkap dengan artikel PDF & 200 \\
\hline Total jurnal hasil pengecekkan duplikasi & 200 \\
\hline Total jurnal dengan publisher yang jelas & 195 \\
\hline Total jurnal masuk tahap $Q A$ & 181 \\
\hline
\end{tabular}

Mengacu kepada diagram Prisma hasil tahap seleksi $Q A$ didapatkan hasil pada Tabel 2.

Tabel 2. Tabel Seleksi Kriteria Quality Assesment

\begin{tabular}{ll}
\hline \multicolumn{1}{c}{ Quality Assesment (QA) } & Jumlah \\
\hline QA1. apakah paper jurnal membahas mengenai covid 19? & 195 \\
\hline $\begin{array}{l}\text { QA2. apakah paper jurnal menuliskan metode pengumpulan upaya } \\
\text { pencegahan covid? }\end{array}$ & 125 \\
\hline Total jurnal masuk tahap sintesa data & 125 \\
\hline
\end{tabular}

Hasil proses pengumpalan data dengan melalui beberapa tahapan beberapa seleksi kriteria menghasilkan total 125 jurnal yang valid untuk dilakukan proses analisis sintesa data untuk menjawab RQ: Upaya apa saja yang banyak direkomendasikan dalam pencegahan covid-19?.

\section{HASIL DAN PEMBAHASAN Laporan Sintesis Data}

Secara keseluruhan terdapat 200 jurnal yang telah didapat melalui proses pengumpulan data pada database Scopus dan Google Scholar. Jurnal diseleksi kembali berdasarkan kriteria inklusi dan eksklusi, selanjutnya jurnal tersebut diseleksi untuk melihat kesesuaian isi dengan kajian $R Q$ berdasarkan $Q A$, sehingga terdapat 125 jurnal yang relevan untuk direview oleh tim peneliti dengan membaca isi dari keseluruhan jurnal. Beberapa jurnal dapat dilihat pada Tabel 3 dengan penandaan berdasarkan No. Indeks dan Judul Jurnal.

Tabel 3. Daftar Review Jurnal Covid-19

\begin{tabular}{|c|c|}
\hline $\begin{array}{l}\text { No. } \\
\text { Indeks }\end{array}$ & Judul Jurnal \\
\hline 1 & Efektivitas Pembatasan Sosial Berskala Besar Di Indonesia Dalam Penanggulangan Pandemi Covid-19 \\
\hline 2 & Pengetahuan Terkait Usaha Pencegahan Coronavirus Disease (COVID-19) Di Indonesia \\
\hline 3 & $\begin{array}{l}\text { Langkah Taktis Pemerintah Daerah Dalam Pencegahan Penyebaran Virus Corona Covid-19 Di } \\
\text { Indonesia }\end{array}$ \\
\hline 4 & Urgensi Pembentukan Aturan Terkait Pencegahan Covid-19 Di Indonesia \\
\hline 5 & Tingkat Pengetahuan Dan Perilaku Masyarakat Kabupaten Wonosobo Tentang Covid -19 \\
\hline 6 & $\begin{array}{l}\text { Edukasi Penerapan Perilaku Hidup Bersih Dan Sehat (PHBS) Sebagai Upaya Pencegahan Penyebaran } \\
\text { Covid-19 }\end{array}$ \\
\hline 7 & Pengetahuan, Sikap Dan Keterampilan Masyarakat Dalam Pencegahan COVID-19 Di DKI Jakarta \\
\hline 8 & $\begin{array}{l}\text { Pengaruh Kebijakan Social Distancing Pada Wabah COVID-19 Terhadap Kelompok Rentan Di } \\
\text { Indonesia }\end{array}$ \\
\hline 9 & A Trial Of Lopinavirâ€"Ritonavir In Adults Hospitalized With Severe Covid-19 \\
\hline
\end{tabular}




\begin{tabular}{|c|c|}
\hline 10 & $\begin{array}{l}\text { Hambatan, Solusi Dan Harapan: Pembelajaran Daring Selama Masa Pandemi Covid-19 Oleh Guru } \\
\text { Sekolah Dasar }\end{array}$ \\
\hline 11 & Olahraga Rutin Untuk Meningkatkan Imunitas Pasien Hipertensi Selama Masa Pandemi COVID-19 \\
\hline 12 & $\begin{array}{l}\text { Meningkatkan Keaktifan Siswa Dalam Pembelajaran Daring Melalui Media Game Edukasi Quiziz Pada } \\
\text { Masa Pencegahan Penyebaran Covid-19 }\end{array}$ \\
\hline 13 & $\begin{array}{l}\text { Penyaluran Alat Pencegahan Dan Sosialisasi Protokoler Kesehatan Untuk Pelayanan Kunjungan } \\
\text { Wisatawan Dalam Menghadapi New Normal Pasca Pandemi Covid-19 }\end{array}$ \\
\hline 14 & Darurat Moderasi Beragama Di Tengah Pandemi Corona Virus Desease 2019 (Covid-19) \\
\hline 15 & $\begin{array}{l}\text { Penetapan Karantina Wilayah Menurut Pandangan Legal Positivisme Dalam Rangka Pencegahan Dan } \\
\text { Pemberantasan Pandemi Coronavirus Disease (Covid)-19 }\end{array}$ \\
\hline 16 & Peran Mikronutrisi Sebagai Upaya Dalam Pencegahan Covid-19 Febry \\
\hline 17 & $\begin{array}{l}\text { Perilaku Dan Peran Tokoh Masyarakat Dalam Pencegahan Dan Penanggulangan Pandemi Covid -19 Di } \\
\text { Desa Jayaraga, Kabupaten Garut }\end{array}$ \\
\hline 18 & $\begin{array}{l}\text { Dampak Pandemi Covid-19 Terhadap Kegiatan Belajar Mengajar Di MI/SD (Studi KBM Berbasis } \\
\text { Daring Bagi Guru Dan Siswa) }\end{array}$ \\
\hline 19 & Persepsi Mahasiswa PIAUD Terhadap Kuliah Online Di Masa Pandemi Covid 19 \\
\hline 20 & Dampak Covid-19 Terhadap UMKM Di Indonesia \\
\hline 21 & $\begin{array}{l}\text { Characteristics Of And Important Lessons From The Coronavirus Disease } 2019 \text { (COVID-19) Outbreak } \\
\text { In China: Summary Of A Report Of } 72314 \text { Cases From The Chinese Center For Disease Control And } \\
\text { Prevention }\end{array}$ \\
\hline 22 & Kegiatan Relaksasi Sebagai Coping Stress Di Masa Pandemi Covid-19 \\
\hline 23 & Penyakit Virus Corona 2019 \\
\hline 24 & $\begin{array}{l}\text { Perbedaan Efektivitas Handsanitizer Dengan Cuci Tangan Menggunakan Sabun Sebagai Bentuk } \\
\text { Pencegahan Covid-19 }\end{array}$ \\
\hline 25 & Virological Assessment Of Hospitalized Patients With COVID-2019 \\
\hline 26 & $\begin{array}{l}\text { Pemberdayaan Karang Taruna Dalam Pencegahan Penyebaran Covid-19 Di Desa Wonokerto } \\
\text { Kecamatan Wonogiri }\end{array}$ \\
\hline 27 & $\begin{array}{l}\text { Pandemi Covid-19 Dan Online Learning : Apakah Berpengaruh Terhadap Proses Pembelajaran Pada } \\
\text { Kurukulum 13? }\end{array}$ \\
\hline 28 & $\begin{array}{l}\text { Implementasi Sistem Pakar Menggunakan Metode Certainty Factor Untuk Mendiagnosa Dini Corona } \\
\text { Virus Desease (Covid-19) }\end{array}$ \\
\hline 29 & Dampak Covid-19 Terhadap Kegiatan Pembelajaran Online Di Perguruan Tinggi Kristen Di Indonesia \\
\hline 30 & $\begin{array}{l}\text { Clinical Course And Risk Factors For Mortality Of Adult Inpatients With COVID-19 In Wuhan, China: } \\
\text { A Retrospective Cohort Study }\end{array}$ \\
\hline$\ldots$ & $\ldots$ \\
\hline 125 & Belajar Dari Rumah Dalam Masa Darurat Covid-19 \\
\hline
\end{tabular}

Keterangan: File jurnal dapat diakses pada link berikut https://bit.ly/3AsIBWL

Hasil pada tahap ini menunjukkan jawaban dari RQ yang telah ditetapkan, yaitu:

RQ : Upaya apa saja yang banyak direkomendasikan dalam pencegahan covid-19?

RQ ini bertujuan untuk mendapatkan upaya yang paling banyak direkomendasikan dalam pencegahan Covid-19 dengan metode pemeringkatan, melihat upaya yang paling banyak disebutkan dalam setiap jurnal. Hasil upaya pencegahan penularan Covid-19 yang direkomendasikan dari setiap jurnal terkumpul 37 upaya pencegahan penularan Covid-19 berasal dari Tabel 3. Pembacaan tabel daftar upaya pencegahan Covid-19 dapat dilihat baris tabel kiri ke kanan, seperti ditunjukkan pada Tabel 4. 
Tabel 4. Daftar Upaya Pencegahan Covid-19

\begin{tabular}{|c|c|c|c|c|c|}
\hline No & Upaya Pencegahan & Indek Jurnal & No & Upaya Pencegahan & $\begin{array}{c}\text { Index } \\
\text { Jurnal } \\
\end{array}$ \\
\hline 1. & Social Distancing & $\begin{array}{l}8,9,14,15,17,22,27,3 \\
7,39,43,46,47,51,52, \\
54,56,57,60,63,66,6 \\
7,68,72,75,79,81,88, \\
93,98,105,106,108,1 \\
, 112,114,115,121,12 \\
4,110\end{array}$ & 2. & Psbb/Karantina/Lockdwon & $\begin{array}{l}2,4,8,9,15,19,22 \\
33,34,37,38,41, \\
48,52,53,61,63, \\
68,70,76,87,94, \\
106,108,113,12 \\
3\end{array}$ \\
\hline 3. & Mencuci Tangan & $\begin{array}{l}1,5,7,17,24,27,40,66 \\
, 83,88,96,98,106,10 \\
9,114,115,116,118,1 \\
19,120\end{array}$ & 4. & $\begin{array}{l}\text { Work From Home / Study } \\
\text { From Home }\end{array}$ & $\begin{array}{l}3,10,12,18,19,2 \\
0,29,56,57,59,6 \\
0,61,69,70,71,7 \\
2,86,97,99,104, \\
105,112,114,12 \\
5\end{array}$ \\
\hline 5. & Memakai masker & $\begin{array}{l}1,17,26,40, \\
42,43,44,46,50,55,8 \\
8,111,116,118\end{array}$ & 6. & Etika Batuk Dan Bersin & $\begin{array}{l}5,40,43,52,115, \\
120\end{array}$ \\
\hline 7. & $\begin{array}{l}\text { Memakai } \\
\text { Handsanitizer }\end{array}$ & $\begin{array}{l}3,13,24,40,79,84,98 \\
103,115,119,120\end{array}$ & 8. & $\begin{array}{l}\text { Pola Hidup Sehat Dan } \\
\text { Bersih }\end{array}$ & $\begin{array}{l}81,106,107,109, \\
115,122\end{array}$ \\
\hline 9. & Menjaga Imun & $\begin{array}{l}30,45,46,49,55,58,8 \\
9,115\end{array}$ & 10. & Isolasi Diri & $\begin{array}{l}5,9,21,23,27,37, \\
46,64,75,78,91, \\
92,93,95,100,10 \\
2,107,120\end{array}$ \\
\hline 11. & $\begin{array}{l}\text { Menghindari Kontak } \\
\text { fisik Orang sakit }\end{array}$ & 1,52 & 12. & Tidak Menyentuh Wajah & $\begin{array}{l}7,39,40,43,52,1 \\
09,116,119\end{array}$ \\
\hline 13. & Olahraga & $11,32,74,118$ & 14. & Konsumsi Vitamin/Obat & 16,31 \\
\hline
\end{tabular}

\begin{tabular}{|c|c|c|c|c|c|}
\hline 15. & $\begin{array}{l}\text { Ibadah Di rumah } \\
\text { /Penutupan Tempat } \\
\text { Ibadah }\end{array}$ & 37,123 & 16. & Gugus Tugas & 36,73 \\
\hline 17. & Rapid Test/Swab Test & $30,36,108,25$ & 18. & Berjemur & 32 \\
\hline 19. & $\begin{array}{l}\text { Tidak Menyentuh } \\
\text { Binatang }\end{array}$ & 39,118 & 20. & Istirahat yang cukup & 74 \\
\hline 21. & Upacara Keagamaan & 73 & 22. & Pengecekan Suhu Tubuh & 3 \\
\hline 23. & $\begin{array}{l}\text { Menyemprotkan } \\
\text { Disinfektan }\end{array}$ & $\begin{array}{l}7,35,39,52,64,82,85, \\
101\end{array}$ & 24. & $\begin{array}{l}\text { Meniadakan Hari Bebas } \\
\text { Kendaraan (Car free day) }\end{array}$ & 3 \\
\hline 25. & $\begin{array}{l}\text { Menjaga Kebersihan } \\
\text { Diri }\end{array}$ & $6,20,54,107,121$ & 26. & $\begin{array}{l}\text { Pembatasan Kapasitas } \\
\text { Peserta Kegiatan }\end{array}$ & 22 \\
\hline 27. & Relaksasi Psycologis & 22 & 28. & $\begin{array}{l}\text { Pemasangan Poster } \\
\text { Himbauan }\end{array}$ & 26 \\
\hline 29. & $\begin{array}{l}\text { Membuat Sistem } \\
\text { Pakar Mendeteksi } \\
\text { Dini Infeksi Covid }\end{array}$ & 28 & 30. & Memakai Sarung Tangan & 50 \\
\hline 31. & $\begin{array}{l}\text { Mematuhi Protocol } \\
\text { Kesehatan }\end{array}$ & $73,62,92,117$ & 32. & $\begin{array}{l}\text { Terapi Investigasi Anti } \\
\text { Trombotik / Pernapasan }\end{array}$ & 77 \\
\hline 33. & $\begin{array}{l}\text { Diplomasi } \\
\text { Publik(Martha, } \\
\text { 2020)(Martha, 2020) }\end{array}$ & 80 & 34. & $\begin{array}{l}\text { Pemasangan Sawen / } \\
\text { Kepercayaan }\end{array}$ & 90 \\
\hline 35. & $\begin{array}{l}\text { Pengobatan } \\
\text { Konsultasi Secara } \\
\text { Online }\end{array}$ & 93 & 36. & $\begin{array}{l}\text { Wajib Lapor Jika Ada } \\
\text { Warga Yang Datang Dari } \\
\text { Luar Kota }\end{array}$ & 114 \\
\hline 37. & $\begin{array}{l}\text { Tidak mengkonsumsi } \\
\text { daging yang tidak } \\
\text { dimasak }\end{array}$ & 118 & & & \\
\hline
\end{tabular}

Keterangan: Index Jurnal merupakan setiap jurnal yang direview per judul artikel 
Berdasarkan Tabel 3 didapatkan 10 upaya pencegahan tertinggi yang paling banyak direkomendasikan berdasarkan menghitung total judul artikel yang mengindex upaya dalam daftar tabel upaya pencegahan Covid-19. 10 upaya tertinggi ini diperingkatkan berdasarkan upaya pencegahan yang mendapatkan paling banyak direkomendasikan dari 125 jurnal. Peringkat 10 upaya pencegahan ditunjukkan pada Gambar 6.

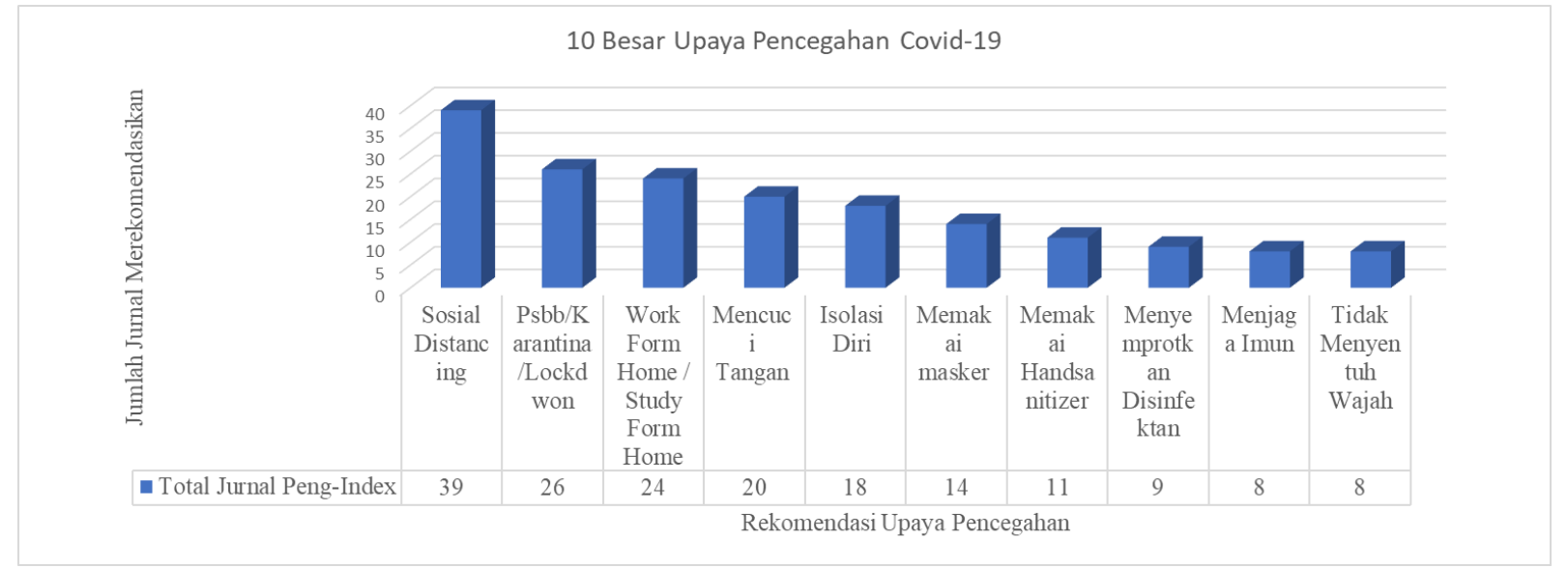

Gambar 6. 10 Upaya Pencegahan Covid-19

10 upaya tertinggi pencegahan Covid-19 yang dapat dilakukan untuk mencegah penyebaran adalah social distancing 39 jurnal, Karantina/lockdown/PSBB 26 jurnal, Work From Home (WFH) 24 jurnal, Mencuci tangan 20 jurnal, Isolasi diri 18 jurnal, Memakai masker 14 jurnal, Memakai handsanitizer 11 jurnal, Menyemprotkan disenfektan 9 jurnal, Menjaga imun 8 jurnal, Tidak menyentuh wajah 8 jurnal, semua didapat dari 125 jurnal yang telah direview.

\section{KESIMPULAN DAN SARAN}

Berdasarkan penelitian, dapat disimpulkan untuk menangani masalah dalam upaya pencegahan Covid-19 didapatkan 10 upaya yang banyak direkomendasikan, dari 37 upaya pencegahan yang terdefinisi di dalam 125 jurnal menggunakan metode Systematic Literature Reviews. 10 upaya terbanyak yang direkomendasikan adalah Social distancing, Karantina/lockdown/PSBB, WFH Mencuci tangan, Isolasi diri, Memakai masker, Memakai handsanitizer, Menyemprotkan disenfektan, Menjaga imun, dan Tidak menyentuh wajah. Hal menarik yang didapatkan juga dalam penelitian ini ternyata terdapat upaya yang tidak hanya dibangun berdasarkan ilmu medis, namun juga dikaitkan dengan kepercayaan seperti, Pemasangan Sawen dan Upacara Keagamaan.

\section{REFERENSI}

Afrianto, Y., Wulandari, B., \& Ginting, N. B. (2020). Method of Systematic Literature Review for Identification of Lecture Scheduling Information Systems. Jurnal Teknik Informatika C.I.T Medicom, 12(2), 41-48. https://doi.org/10.35335/cit.Vol12.2020.35.pp41-48

Hastuti, V., Mongkito, R., Sukariasih, L., Sahara, L., Fisika, J. P., Oleo, U. H., Tempat, P., Tangan, C., \& Masyarakat, P. K. (2021). Edukasi Masyarakat dalam Upaya Penanggulangan Covid-19 Melalui Cara Pembuatan Tempat Mencuci Tangan. ABDIMASA Pengabdian Masyarakat, 4(2), 1-7.

Kementerian Kesehatan RI. (2020). Pedoman Pencegahan dan Pengendalian Corona Virus deases (Covid-19). Kementrian Kesehatan, 5, 178. https://covid19.go.id/storage/app/media/Protokol/REV-05_Pedoman_P2_COVID19_13_Juli_2020.pdf

Kurniawan, A. (2020). Ketakpastian Penyelenggaraan PSBB dalam Penanganan COVID-19. Artikel Blog [Daring]. http://smeru.or.id/id/content/ketakpastian-penyelenggaraan-psbb- 
dalam-penanganan covid-19

Martha, J. (2020). Pemanfaatan Diplomasi Publik oleh Indonesia dalam Krisis Covid-19. 7(April).

Moudy, J., \& Syakurah, R. A. (2020). 002. Pengetahuan terkait usaha pencegahan Coronavirus Disease (COVID-19) di Indonesia. Higeia Journal of Public Health Research and Development, 4(3), 333-346.

Refialdinata, J. (2020). Analisis Upaya Pencegahan Covid-19 pada Masyarakat Kampus. Jurnal Ilmiah Multi Science Kesehatan, 12(2), 58-68.

Telaumbanua, D. (2020). 004. Urgensi Pembentukan Aturan Terkait Pencegahan Covid-19 di Indonesia. QALAMUNA: Jurnal Pendidikan, Sosial, Dan Agama, 12(01), 59-70. https://doi.org/10.37680/qalamuna.v12i01.290

Thorik, S. H. (2020). 001. Efektivitas Pembatasan Sosial Berskala Besar Di Indonesia Dalam Penanggulangan Pandemi Covid-19. Jurnal Adalah : Buletin Hukum Dan Keadilan, 4(1), $115-120$. 